\title{
The Implementation of India's Maritime Doctrine to Respond China Naval Presence in Indian Ocean Region
}

\author{
Anak Agung Banyu Perwita ${ }^{1}$, Fadhlur Rivanda ${ }^{2}$ \\ ${ }^{1}$ President Center for International Studies (PRECIS), School of International Relations, \\ President University, Cikarang \\ ${ }^{2}$ President Center for International Studies (PRECIS), School of International Relations, \\ President University, Cikarang \\ aabanyu.perwita@gmail.com
}

\begin{abstract}
Indian Ocean is a strategic and crucial ocean for the world and has become the centre of global politics. Indian Ocean Region (IOR) has several important gulfs, straits, bays and seas within which most of it located in the northern part of the ocean. Major shipment routes intersect its enormous area, with crucial choke points and water courses connecting Indian Ocean to other main ocean parts on the earth. The region of Indian Ocean constitutes a significant portion of China's security interests, where China is currently leading to an ever advanced military existence within the area. China's overpowering strategic focus in the Indian Ocean is the preservation of their maritime trading routes, particularly those transporting oil and gas that the Chinese economy relies upon. Indian Ocean Region is prioritized in the Indian foreign and defense policy interests. India is definitely trying to maintain its national security interests in Indian Ocean from any possible threats. In response to the condition in the Indian Ocean, India implemented its Indian Maritime Doctrine which is applied through Indian Navy as the way to respond China's naval existence in IOR since 2008. This implementation brings the sources of its naval application as an effort to balance China's naval presence in IOR through its maritime doctrine. The unilateral naval effort is held to respond China in IOR. Moreover, a further effort of Indian navy is needed through bilateral and trilateral cooporation that will further support its unilateral effort in balancing China's active presence in the region.
\end{abstract}

Keywords: Indian Ocean Region, China, Maritime Doctrine, India, National Security.

\section{INTRODUCTION}

The length of the Indian Ocean is $1.000 \mathrm{~km}$ that stretches all the way from the southern part of Africa to Australia, and it spreads from the Persian Gulf to Antarctica about nearly $13.500 \mathrm{~km}$. Indian Ocean Region (IOR) has many important straits, gulfs, bays and seas at intervals that the foremost of them being within the northern half. Most important shipping lanes crisscross its massive area, with strategic waterways and choke points connecting the Indian Ocean to the other part of key water areas on earth. Good geo-strategic is one of the important thing for the continuance of "maritime power", as the islands and archipelagos are scattered and become the striking features of Indian Ocean region (Ministry of Defense (Navy), 2009). India's Chief of Naval Staff, Admiral Sureesh Mehta stated that the first decade of the twenty-first century has seen changes and instability in the IOR, especially within the areas of India's national interests (Ministry of Defense (Navy), 2009).

According to PM Modi, $90 \%$ of India's trade by volume and oil imports is transported through the sea. Likewise, India has a coastline length of $7500 \mathrm{~km}, 1200$ islands and 2.4 million square kilometers of Exclusive Economic Zone (EEZ) which explains the complementary presence of India as being globally united. He continued that India will heavily rely on the ocean and the government must take proper actions to 
shape the future of India's marine interests. India's vision for Indian Ocean Region is profound in previous cooperation within the region and to utilize their capabilities for the benefit of all parties of the region. (PM INDIA, 2015).

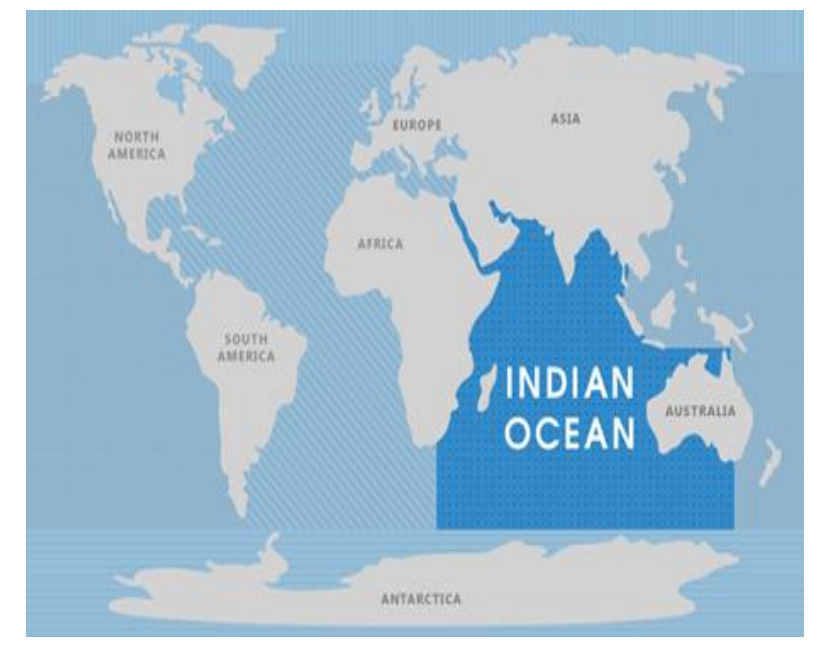

Figure 1. Map of Indian Ocean (whatarethe7continents, 2018)

However, there are also primary security interests around the Indian Ocean region for those who are geographically located in the area, where they are more concern about their economy and the livelihoods of their people. US, China and Japan, for instance, are major power who have interests and play significant roles in the region. The interests of the Middle power countries are also there and these middle power actors include such countries like the Republic of Korea (ROK) and Australia. The US and the European countries also put their big concern of their interest in the region (India Foundation, 2016). In sustaining their political economy, the countries categorized as developed and developing countries believe deeply on continuous offer of oil from gulf with the oil-flow through the Straits of Hormuz itself being larger than fortieth of the worldwide oil trade. The new term "Silk Route" was given to the maritime curve that stretches from the Gulf through the Strait of Malacca to the ocean of Japan. The region has consequently become the theatre for extra regional powers to demonstrate their increased presence to protect their strategic interest (Ministry of Defense (Navy), 2009).

Since 1970s The U.S. maintained the ocean region becomes the strategic importance to its important interest. With the bottom support provided from Diego Garcia and thru bilateral engagements within the Gulf and also the Association of Southeast Asian Nations, through Asia-Pacific to Japan, wherever this action showed USA because the most noticeable and powerful extra-regional power within the IOR. France is considering ocean power with a major armed service presence within the IOR. This is often as a result of France has many islands territories within the IOR to be preserved. Within the last decades, Japan, some major EU countries, China and Russia have significantly raised their presence in IOR, either unilaterally or through politico-security engagements (Ministry of Defense (Navy), 2009). Trade routes that taste the ocean are quite crucial, especially for Chinese economy that they were extremely reliant on the IOR, particularly for the availability of energy. Therefore, the 
Chinese government is seeking to safeguards its interests on these ocean lines of communication (Cooper, 2018).

To survive and manage its national sovereignty in Indian Ocean region, India needs to maintain their national security interests in Indian Ocean. National maritime sovereignty is the main national security interest for India in Indian Ocean which is very significant for their national security. As well the trader outset that is very beneficial for the economic growth for India itself. India basically needs to protect the Indian Ocean Region as their maritime strategic environment. Moreover, Indian Minister of State (MoS) for Defense Rao Inderjit Singh stated that the Indian Ocean Rim, in particular the sea lines that pass through it, is vital for the nation's economic growth (PTI, 2018a).

The aim of this article is to decipher the military respond of India toward the naval presence of China in IOR. Furthermore, this article aims to answer the question on how India implemented its maritime doctrine to maintaining its national security interests towards China naval presence in Indian Ocean Region. The main argument of this article is that it is more than necessary for India to implement its maritime doctrine in responding to the growing presence of China's naval forces and protecting India's strategic interests in IOR.

China is the most active state actor in the area, according to 2004 report for the United States Department of Defense, the term "string of pearls" was first of all accustomed to confer with Chinese basing access within the Indian Ocean (Cooper, 2018). The interdependencies between China and varied South Asian states have been developed through oppression of the Maritime Silk Road. It embraces countries loaded by monumental Chinese liability, chartered out its Hambantota Port project to Chinese state-controlled bodies and Pakistan, for whom as a subset of the "ChinaPakistan-Economic-Corridor (CPEC)" and providing China the geo-strategic opportunity to develop the Gwadar Port. The negotiation was presented towards numerous of these countries by the institutions of free-trade agreements with China (Mukherjee, 2018).

Based on Chinese official state media, Xinhua reported that within the western part of the ocean, the primary preparation capability of China was to control the readiness of its naval forces, such as the "destroyer Changchun, guided-missile frigate Jingzhou" and therefore the supply vessel Chaohu held a live-fire ram down realm of the western ocean waters. The explanation behind this naval presence is to monitor "enemy" surface ships (Xinhua, 2017). The "enemy" was not specifically expressed. However, it is apparent that the rival was the Indian Navy, which suggests why the drill is assumed to be a warning shot to India ( $\mathrm{Ng} \&$ Jiangtao, 2017)

This situation then, according to some analysts, has been described as a growing military rivalry between China and India that might lead to the increased tension between the major power in IOR (Samaranayake, 2017). 


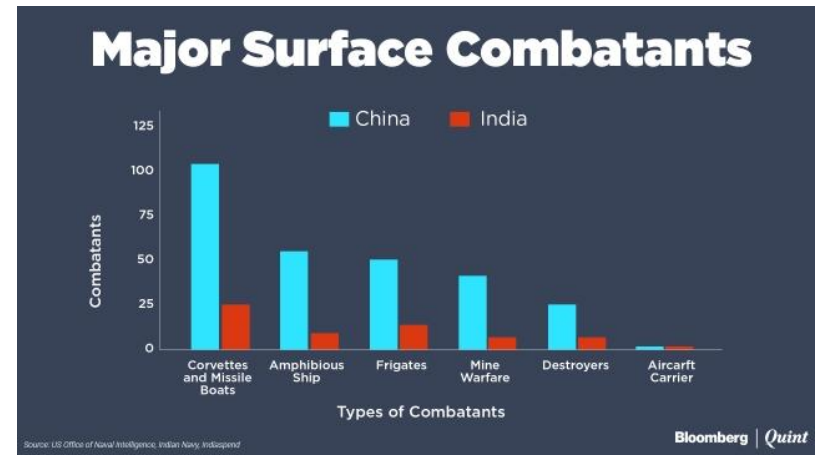

Figure 2. India Naval Combats in Indian Ocean (Sethi, 2017)

The capabilities of the Indian Navy in the area are much smaller compared to China's naval capabilities deployed in the Indian Ocean (Figure 2). The capabilities of China's naval are four times higher than the Indian Navy, with only 66 warships in total. China's People's Liberation Army Navy (PLA-N) has a total of 283 major surface combatant warships deployed in the Indian Ocean. Those 283 major surface combatant warships include Corvettes and Missile Boats, Amphibious Ships, Frigates, Mine Warfare's, Destroyers and Aircraft Carriers. This data shows the real presence of the Chinese Navy in the said ocean according to an India Spend analysis (Sethi, 2017).

China's naval activities in Indian Ocean have increased since 2008 and have made an agreement with Djibouti for the building of military base under the banner of "military supporting facilities". China deployed naval ships in the area of 'Gulf of Aden' on December 2008. Moreover, China's growing activities in this region observed through the existence of its naval allowed deployments in the following years. China has sent a nuclear submarine to Indian Ocean, specifically to the Malacca Strait on December 2013. The naval deployment in 2013 was not the end of china presence in Indian Ocean. On February 2014, China held a task force traversed in Sunda Strait which aims to conduct China's first naval drills south of Indonesia.

India is very agitated about the buildup of China's interdependencies establishment and the China's ports project in Indian Ocean, particularly in Gwadar, Pakistan, as the Director of India national Maritime Foundation, Pradeep Chauhan, stated to VOA News that there is a higher probability of the rivalry to escalate into conflict areas as China starts to develop facilities in the ocean (Pasricha, 2018).

National maritime sovereignty is the main national security interest for India in the Indian Ocean which is very significant for their national security, as well the trader outset that is very beneficial for the economic growth for India itself. India basically needs to protect the Indian Ocean Region as their maritime strategic environment. Moreover, Indian Minister of State (MoS) for Defense, Rao Inderjit Singh said that the Indian Ocean Rim, in particular the sea lines that pass through it, is vital for the nation's economic growth (PTI, 2018a). Despite the interests offered by the Indian Ocean Region, India has perceived their threat perception towards other party in the ocean itself. It is not simply concerning the ocean, it is concerning the potential threats of China in the ocean. Both the Indian Ocean and its encompassing waters are very crucial for China's major shipment lanes, which explain the essential effort to protect its economic and energy security from opposing parties aiming to restrict China's access 
to those waters. China has entered on a plan to represent an announcement support base within the IOR that might later be leveraged militarily. The existence of China's navy in the Indian Ocean alerted India and is perceived to be a possible threat. To respond this possibility, India planned its defense program through The Indian Maritime Doctrine; a document which was published in 2004 and revised in 2009. This publication is aimed to express the Navy's maritime strategic outlook, outline the framework of its service, and contribute overall steerage for its progression as a counter force (Ministry of Defense (Navy), 2009). The strategic contestation between both countries in the region has raised a lot of distress from neighboring states.

\section{RESEARCH METHOD}

This study utilizes a qualitative research method. The data is gained from a focused review of relevant theories, literature, and previous research findings of the discussed topic. Then it converts both primary and secondary sources in addressing the issue of the topic will be discussed. Similarly, the data gained from both sources serves to validate the findings of this study.

\section{THEORETICAL FRAMEWORK}

\section{THE REGIONAL MARITIME SECURITY OUTLOOK OF INDIAN OCEAN AND INDIA'S MARITIME DOCTRINE}

The role of maritime security is to organize relations, replace or incorporate older, fixed concepts and relate it more with newly developed ones (Bueger, 2015, sec. Conceptual relations: A maritime security matrix). Naturally, there is a linkage between National Security, Defense Policy, Maritime Doctrine and Maritime Security. National Security is the main interest for a state. In responding the potential and existential threats, the state produces its defense policy to respond both traditional and nontraditional security issues. Maritime security, in doing so, is one of the defense policy concerns and Maritime Doctrine acts as the strategy for a state to tackle maritime security threats which may harm its national security.

While one of the main approaches of maritime security is sea power which has closely connection with maritime doctrine (Agastia \& Perwita, 2016). Referring to the Indian Navy document, "Maritime is a blanket word, together with everything that's connected to the seas. The Indian Maritime doctrine, however, deals specifically with the ideas and principles of employment of India's armed service power' (Ministry of Defense (Navy), 2009), as drawn in Diagram 1 below. 


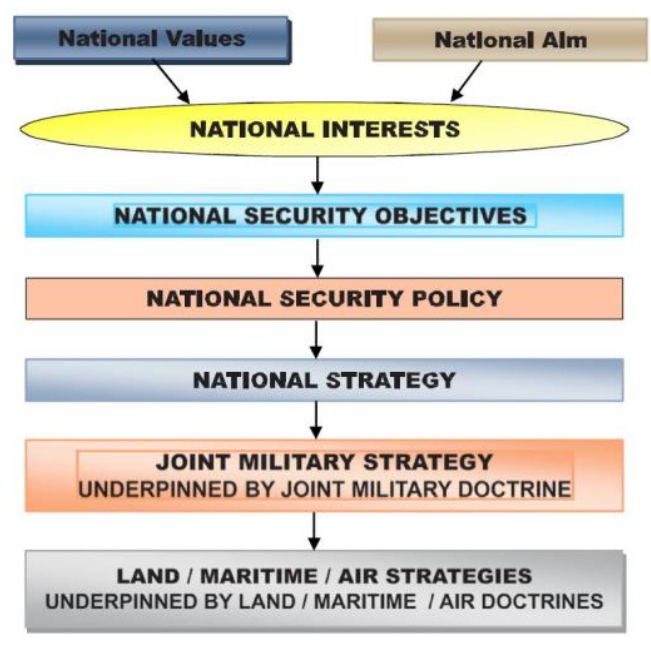

Diagram 1. National Security Concept and Doctrines (Ministry of Defense (Navy), 2009)

Based on Indian National Security Concepts and Doctrines, the combination of National Values and National Aim creates National Interests and it shapes the National Objectives then impacts the National Security Policy making. Furthermore, the implementation of its policy becomes the National Strategy, which might be in the form of Joint Military Strategy (Underpinned by Joint Military Doctrines) and makes it as the Land/Maritime Strategies (Underpinned by Land/ Maritime/ Air Doctrines). National values were developed from a nation's culture and history. The National Aim springs from the Constitution of Bharat and are boosted through political directions. The combination of national values and national aim, then, offers form to National Interests that then confirm the National Security Objectives" (Ministry of Defense (Navy), 2009).

Geopolitics may be a poetical activities command at the intervals of the nation or space. Besides, the geographical areas of politics were called the strategic surroundings. The inner and external context, conditions, relationships, trends, issues, threats, opportunities, interactions, and effects is consisted within the strategic surroundings which might affect the state's accomplishment in regard to the physical world, alternative states and actors, probability and feasible futures (Yarger, 2006).

As it to understand, the maritime doctrine acts as a bridge towards a state actor in order to preserve its national interest, especially its maritime security interest which is also influenced by its geopolitics. The application of Maritime doctrine is mainly about the principles and ideas of its armed service power employment.

\section{RESULT AND DISCUSSION}

\section{THE STRATEGIC ENVIRONMENT OF THE INDIAN OCEAN}

As the littoral's most populated country in Indian Ocean, India is very reliant on this ocean. According to the Shipping Corporation of India's annual report of the years $2015-2016,95 \%$ of India's trade by volume and $68 \%$ of trade by value come from the Indian Ocean (The Shipping Corporation of India Limited., 2016). Furthermore, FAO stated that India is reliant on the deposits present in the ocean. In 2008, India was 
placed sixth in the world for accumulating 4.1 million tons of fish and employ around 14 million people in its fishing and aquaculture industries (Food and Agriculture Organization, 2016). Based on the Indian Defense document, the engagement of India in the Indian Ocean has strong security measures, which is a far cry from its traditional naval aspect (Ministry of Defense (Navy), 2009). India considered IOR as a crucial area since the importance of it towards their economic interest, political interest and security interest in the region.

The ocean is very important for India, especially for their economic growth. Indian Ocean is located within the intersection of global trade that connects the international economy of Northern Atlantic and Asia-Pacific, in which almost 90,000 ships convey 9.14 billion tons annually (Jaishankar, 2016). The resources found in the Indian Ocean are something that led India to be deeply reliant on. In 2008, India netted 4.1 million tons of fish, retaining it sixth in the world. Moreover, India employed about 14 million people within the fishing and aquaculture industries (Food and Agriculture Organization, 2016). A major source of exports is also made from aquaculture and fisheries industries. India's maritime export increased around 55 times in volume within a 50-year period (1962-2012). The exports of fisheries currently account Rs. 16,600 core or about $\$ 2.65$ billion (Central Institute of Fisheries Technology (CIFT), 2018).

Expanding its existence and activity in the Indian Ocean to protect its marine power in the region is India's firsthand political interests. The political interests of India in the Indian Ocean could be seen as a geopolitics aspect. World politics is highly influenced by the oil conditions. Geographically speaking, Indian Ocean is a strategic location for international trading route of oil and gas, especially through the Strait of Malacca and Straits of Hormuz (Fatima \& Jamshed, 2015). This condition creates a competition among the parties in the region, and even parties outside the region.

Realizing Indian Ocean as a strategic environment, India conducts its political activities in the region by having cooperation with other surrounding states which aims to secure the Indian Ocean strategic area. The coordination of maritime security between Mauritius, the Maldives, Sri Lanka, Seychelles and India, originated in 2011 by means of a "trilateral India-Sri Lanka-Maldives arrangement" (Ghosh, 2014). Joint cooperation has been taken to avoid irrelevant and potentially destructive maritime competition in the Ocean. India have politically participated in the Indian Ocean Naval Symposium together with 35 other members and pursues to enhance maritime security cooperation among the IOR littoral states navies (Pisupati, 2015).

China's building up naval existence in Indian Ocean region has triggered India's concerns over the region. China has deployed its naval capabilities in Indian Ocean and it is much bigger compared to the capabilities of Indian Navy in the area. The capabilities of China's naval are four times higher than the Indian Navy, with only 66 warships in total compared to China's People's Liberation Army Navy (PLA-N) 283 major surface combatant warships all deployed in the Indian Ocean. Those 283 major surface combatant warships included Corvettes and Missile Boats, Amphibious Ships, Frigates, Mine Warfare's, Destroyers and Aircraft Carriers. This data showed the reality of China naval presence in Indian Ocean based on India Spend (Figure 2) (Sethi, 2017). 


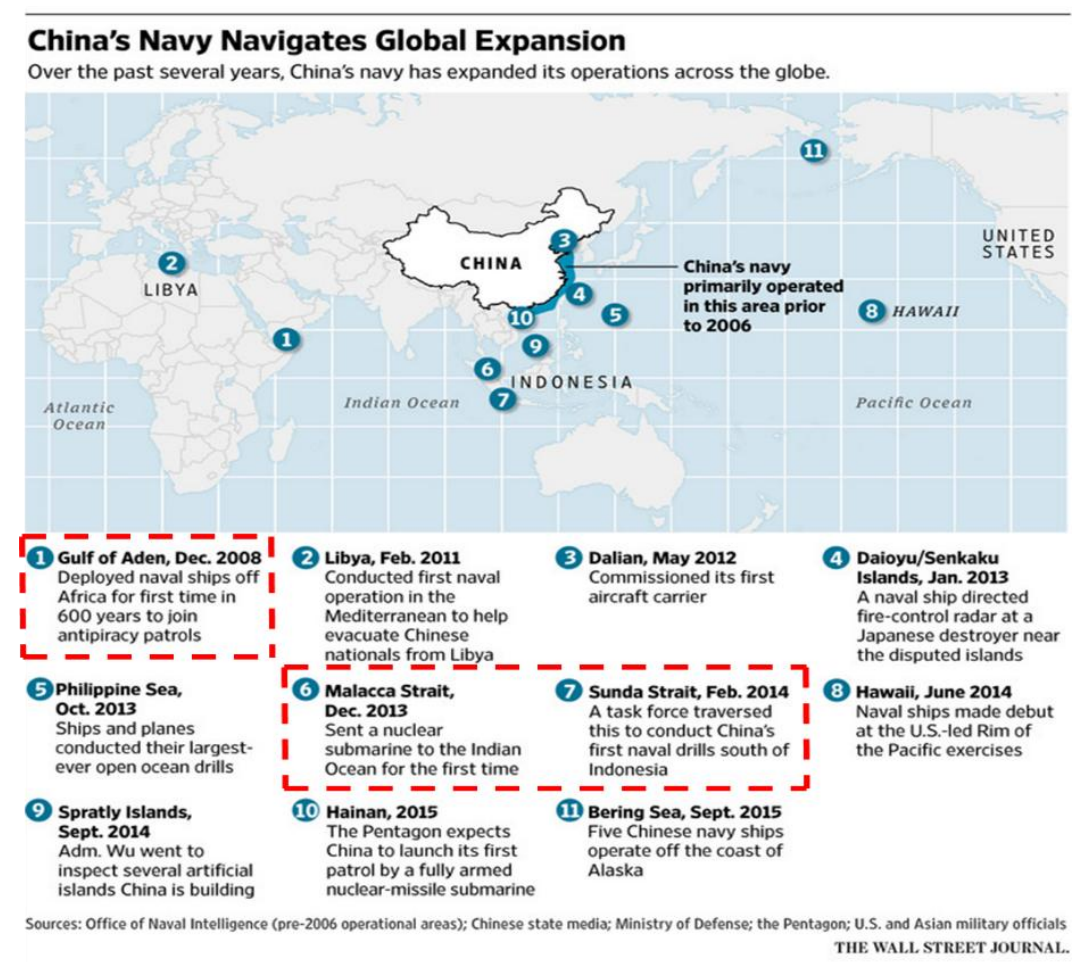

Figure 3. China Naval increasing activities in Indian Ocean (Page \&

Lubold, 2015)

China naval increasing activities in Indian Ocean have been increasing since 2008. China deployed naval ships in the area of 'Gulf of Aden' on December 2008. Moreover, the growing of China activities in this region observed through the existence of its naval activates of deployment in the following years. China has sent a nuclear submarine to Indian Ocean, specifically to the Malacca Strait on December 2013. The naval deployment in 2013 was not the end of china presence in Indian Ocean. On February 2014, China held a task force traversed in Sunda Strait which aims to conduct China's first naval drills south of Indonesia (See Figure 3).

The activities mentioned above force India to maintain its (national) marine security interests in the ocean. In 2015, India's Prime Minister Narendra Modi, under the banner of SAGAR (Security and Growth for All in the Region), emphasized that the maritime policy of China in the IOR overlaps with India's goals. PM Modi continued to address that India's goal is to support a trustful and transparent environment, respect international maritime laws by all states; sense and be aware of every state's interests; seek peaceful resolution of maritime issues and increase maritime cooperation among states (PMINDIA, 2015).

Pradeep Chauhanas, Director of National Maritime Foundation in New Delhi, expressed that India's strategic space within its own geographical area has been constricted and emphasized the high possibility of India-China conflict as China starts to develop bases in the Indian Ocean (Pasricha, 2018). The Chinese ships regularly visited the IOR since almost ten years ago. One deployment is the combat deployment which warrants special mention is an exercise that the PLAN started in JanuaryFebruary 2014 when "Surface Action Group (SAG)" involving the "Changbaishan 
YUZHAO-class amphibious transport dock (LPD)", the "Wuhan LUYANG I-class guided-missile destroyer (DDG)", and the "Haikou LUYANG II-class DD"' initiated an exercise and transited in the South China Sea (SCS), Lombok, Sunda and Makassar Straits before exercising in the Philippine Sea, and then returned to Zhanjiang Naval Base in Southern China. "The exercise involved antisubmarine warfare, air defense, electronic warfare, and expeditionary logistics; training to seize disputed islands and reefs in the SCS; improving the ability to conduct incorporated and multi-disciplinary operations; and demonstrate to the Indo-Pacific region that China's combat reach now stretched to the eastern Indian Ocean" (Suri, 2017). India is seriously responding China's increased naval activities in the Indian Ocean as a threat.

\section{INDIA'S MARITIME SECURITY STRATEGY}

The Indian government and relevant officials has altered its maritime security strategy to respond to China's increasing dominance in the IOR. In its 2015 maritime security strategy, titled "Ensuring Secure Seas: Indian maritime Security Strategy", India put the freedom of navigation and security in IOR as its primary objective which has a direct link to India's national interests in the ocean.

The presence of India and China in the 'Indian Ocean' is based on similar strategic interests toward the region. Protecting national and homeland security as well as managing and protecting the environment of the ocean are the national strategies of both countries. Despite both countries sharing similar national interest and priorities in the Indian Ocean, they have different strategies to achieve their own security interest in the area.

In strengthening China's logistical infrastructure, the Chinese port construction and attainment efforts in the Indian Ocean add significant value to the SLOCs. India is getting distressed by China's simultaneous naval modernization efforts in the region. Chinese naval modernization has become the leading navy in Asia by its firm progression, with an abundant of surface submarines and ships. The new standard of China's Navy had converted through its "Far seas exercise and deployments in this region" (Dravid, 2018).

China also develops a counterbalance through the economic and strategic partnerships with several littoral nation-states in the area of IOR in order to strengthen its presence in the region. The other firm patterns to verify China's expanding interests in the IOR is shown through China's investment in Hambantota, Sri Lanka, its electronic collecting facilities in the Bay of Bengal as it is an isolated islands, and the Chittagong Port of Bangladesh (Dravid, 2018). India's naval capabilities in the said ocean are much weaker to China's naval arrangement in the area. The capabilities of China naval is four times bigger than its rival's deployment which only count as 66 in total, while "China's People's Liberation Army Navy (PLA-N)" has 283 major surface combatant warships in total which deployed in Indian ocean. Those 283 major surface combatant warships involved Corvettes and Missile Boats, Amphibious Ships, Frigates, Mine War fares, Destroyers and Aircraft Carriers. This finding showed the reality of China naval presence in Indian Ocean based on India Spend (Sethi, 2017).

India has already taken responsive steps towards Chinese deployments in the IOR where India found rising Chinese existence in the ocean. Although China was not mentioned, India's naval spokesperson stated that the navy's initial attacks on the IOR 
was done annually for overseas deployment but the presence of another regional power has changed the dynamics of the region and required an increase of India's presence (Thakker, 2019). India gave serious response towards China's increasing presence in the Indian Ocean and they would secure its national security interest. Gurpreet Khurana, an Indian Navy captain and executive director of the National Maritime Foundation in New Delhi, India, stated that India's presence in the Indian Ocean is stronger than China's because the latter has to go through various choke points in Southeast Asia, which explains their wider logistic line. He continued that even though China has an aircraft carrier, it would be a while before it could be integrated into an aircraft carrier battle group which would grant them maritime control in the IOR. Khurana finished off by saying that the process above could take two to three decades and emphasized that India still has prominent advantage in comparison to the Chinese navy in the Indian Ocean (Yang, 2018).

\section{THE IMPLEMENTATION OF INDIA'S MARITIME DOCTRINE}

Advancing the Indian maritime doctrine implementation through naval application to respond China's naval increasing presence in Indian Ocean, India has taken action through the unilateral effort by developing their naval capabilities in the region. Furthermore, these efforts of India can help India to balance the presence of China in the region.

From year to year, India's military capability is developing. India is progressing towards a huge military modernization and repair such a time as to prepare for the most hostile situations. It is an effort to posture threats on both the eastern and western surfaces from China, Pakistan, with over aggressiveness, terrorist outfits and Maoists (The Times of India (Mumbai Edition), 2017). As mentioned in the previous part, India perceives China as their external threat, particularly the strategic area of the Indian Ocean. China's active presence in the region is overcome by India through the development of its naval forces in the area; they are balancing China existence in IOR.

In the way to make India's military as a tough force to handle any possible threats from happening, India has developed new military technology in obtaining compulsory, manufacturing weapon, aircraft, naval vessels and others. India's rivals put concerns on nuclear weapons of India and its program of ballistic missiles. In addition, India's big step towards establishing greater defense equipments and technologies only portrays their level of wariness towards threats and wishes to improve the quality of their military to a higher extent. According to Global fire power, the Indian military is compromised of 4,207,250 active and backup personnel in service. Meanwhile resources like aircraft, personnel, helicopters and other resources range across the three services - Army, Air Force and Navy" (The Times of India (Mumbai Edition), 2017).

The Indian Navy is ranked as the fifth major navy in the world. It devises by "fleet tactical submarines, nuclear-powered submarines, conventionally powered submarines, aircraft carrier, destroyers, frigates, amphibious warfare ships, and corvettes". The victory of India during the 1971 war against Pakistan is backed-up by the Navy which plays a vital role during that time. The Navy also played a crucial role in protecting India's interests in the area of Arabian Sea, Indian Ocean, South China Sea, Bay of Bengal(The Times of India (Mumbai Edition), 2017). 
The capabilities of China's naval are four times bigger than its rival's deployment. The Indian navy only deployed a total of 66 major surface combatant warships. China's larger amount of 283 major surface combatant warships includes Corvettes and Missile Boats, Amphibious Ships, Frigates, Mine War fares, Destroyers and Aircraft Carriers (Sethi, 2017). The efforts of India in countering China's presence require increasing capability of its armed forces. The increasing of its armed forces is supported by its defense allocation and expenditure. India's defense expenditure is published in their annual report (Table 1\&2).

Table 1. Service / Department-wise break up of Defense Expenditure/ Estimates (2009-2012) in USD

(US\$ in Million)

\begin{tabular}{|c|c|c|c|c|c|}
\hline \multicolumn{2}{|c|}{ Service/Department } & $\begin{array}{c}2009-10 \\
\text { Actuals } \\
\text { (Rev+Cap) }\end{array}$ & $\begin{array}{c}2010-11 \\
\text { Actuals } \\
\text { (Rev+Cap) }\end{array}$ & $\begin{array}{c}\text { 2011-12 } \\
\text { Actuals } \\
\text { (Rev+Cap) }\end{array}$ & $\begin{array}{c}2012-13 \\
\text { Actuals } \\
\text { (Rev+Cap) }\end{array}$ \\
\hline \multicolumn{2}{|l|}{ Army } & 15045.60 & 16430.33 & 18231.50 & 17381.67 \\
\hline \multicolumn{2}{|l|}{ Navy } & 4538.72 & 5695.03 & 6217.26 & 6716.60 \\
\hline \multicolumn{2}{|c|}{ Air Force } & 6558.17 & 8017.06 & 9213.15 & 8679.65 \\
\hline \multirow[t]{3}{*}{ DDP } & DGOF & 395.17 & -28.00 & -11.89 & -24.32 \\
\hline & DGQA & 123.48 & 118.80 & 143.70 & 145.30 \\
\hline & Total & & & & \\
\hline \multicolumn{2}{|l|}{$R \& D$} & 1695.08 & 2131.27 & 2103.01 & 1914.40 \\
\hline \multicolumn{2}{|l|}{ Total } & 28356.22 & 32364.51 & 35896.73 & 34813.31 \\
\hline
\end{tabular}

Source: India Annual Report 2011-2012

Table 2. Service / Department-wise break up of Defense Expenditure/Estimates (2014-2017) in USD

\begin{tabular}{|l|r|r|r|r|}
\hline & $\begin{array}{c}\text { 2014-15 Actuals } \\
\text { (Rev + Cap) }\end{array}$ & $\begin{array}{c}\text { 2015-16 } \\
\text { Actuals (Rev + } \\
\text { Cap) }\end{array}$ & $\begin{array}{c}2016-17 \\
\text { Actuals (Rev + } \\
\text { Cap) }\end{array}$ & $\begin{array}{c}2017-18 \\
\text { Actuals (Rev + } \\
\text { Cap) }\end{array}$ \\
\hline Army & $18,673.27$ & $17,149.41$ & $18,379.72$ & $21,775.08$ \\
\hline Navy & $5,859.61$ & $5,230.01$ & $5,237.44$ & $5,676.30$ \\
\hline Air Forces & $8,563.61$ & $7,832.89$ & $7,288.03$ & $8,755.88$ \\
\hline DGOF & 257.06 & 165.24 & 300.68 & 298.19 \\
\hline DGQA & 132.55 & 130.06 & 138.88 & 161.03 \\
\hline R\&D & $2,161.05$ & $1,993.39$ & $1,841.64$ & $2,222.81$ \\
\hline Total & $35,647.15$ & $32,501.00$ & $33,86.38$ & $38,874.29$ \\
\hline
\end{tabular}

Source: India Annual Report 2016-2017

Since the fact that the Rupee has slipped from 40 to a US dollar in 2005 to 70 today, the upsurge in capital expenditure has not reserved stride with Rupee depreciation. As a consequence, there has been a flowing effect of postponing or suspending most procurement due to the huge costs involved. The sole way this might be addressed is a joint strategy of higher expenditure of not less than three per cent of GDP on defense and contest it with a focused strategy of indigenization over the next 20 years (Matheswaran, 2018).

Capital expenditure trends have been unpredictable due to the serious deficiencies in the importance rendered to defense modernization plans. In nearly all 
years, the Ministry of Finance pays just lip service to the five-year and 15-year plans put together by the MoD after numerous years of negotiations. Since budget allocations are not carried onward and gap at the end of the year, most attainment plans infrequently follow to their original time agendas. This unfortunate planning further complicates the issue with unpredictable committed liabilities that leaves little for new attainments (Matheswaran, 2018).

Based on the Indian officials, India's capital defense expenditure is about $28 \%$ of the government's total capital expenditure. They also added that the Defense Ministry is tough to recommend and inter service primacy military hardware list for optimum application of the budget, considering the national security objectives (Gupta, 2018). Moreover, one of the officials said that the defense ministry has spent $90 \%$ of the capital expenditure and $82.6 \%$ of the 2017-18 revenue budgets. Nearly Rs 1.42 lakh crore (US\$137.74 Million) were spent out of total 1.72 lakh crore (US\$ 166.84 Million) of the revenue budget, which endures to increase on account of OROP (One Rank One Pension). India have expended 78,000 crore (US\$ 75,660 Million) of our 86,000 crore (US $\$ 83,420$ Million) of the capital expenditure with the Air Force using its whole attainment budget. In 2016-17, the capital expenditure was entirely used (Gupta, 2018).

Nevertheless, China's presence in the western border with its satisfactory capability could prevent any threat from Pakistan, so the key focus of the Indian defense budget expenditure is projected to be lengthways to those 3,488 kilometer Line of Actual Control (LAC). Additionally, the enhancement of the military capabilities and capacities in islands of Andaman Nicobar arranged that the territories assemble on the critical SLOC passing over Malacca Straits into South China Sea capital will be paid (Gupta, 2018). A top Indian naval commander said that to counter China's increasing dominance in the strategically key waters; India clearly set a new maritime strategy for deployment of warships as an effective effort to stabilize the Chinese Navy in the IOR. Navy sources said this new initiative involves a new deployment of mission-ready ships and aircraft across the critical sea lanes of communications namely the "new missionbased deployment" (PTI, 2018b). 


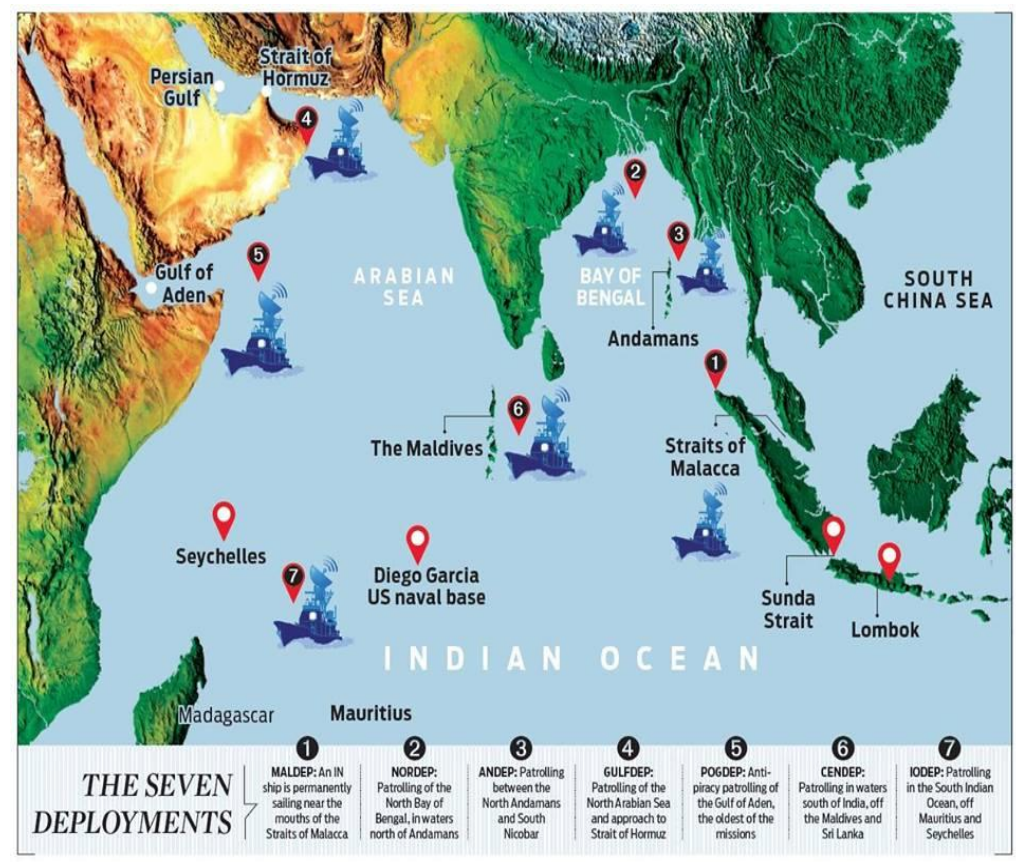

Figure 4. Indian Naval Seven Deployments in Indian Ocean (Dutta, 2018)

According to Dutta's published article, the Indian navy has informed its government of a new set of alphabet soup acronyms (namely MALDEP and GULFDEP) to explain its areas of responsibility since the reorientation of its naval mission blueprint (Dutta, 2018). The re-orientation to Mission based deployments (MDP) has intended that "around 15 warships of the Indian Navy patrol seven areas of the Indian waters which goes beyond the Indian Exclusive Economic Zone (EEZ) and guard all entry and exit routes to and from the Indian Ocean (Figure 4). The ships are tasked to patrol nonstop continuously throughout the year. Each of warships is turned around once three months. The final deployments for the year from the beginning of the new pattern in end of May 2017 and announced in October 2017 have just begun. Warships usually avoid sailing throughout the international maritime highways, except if specifically tasked, and frequently go from point $A$ to point $B$ in zigzag pattern to cover up more area" (Dutta, 2018).To complete round-the-clock surveillance from the Persian Gulf to Malacca Strait, a fleet of 50 of its combat-ready warships is deployed in the Indian Ocean under the Navy's "Mission Based Deployment" program (Boquérat, 2018).

Compliance of militarily access to the strategically deep-sea Sabang port in Aceh, Indonesia and Oman's Duqm port are the products of India's negotiation agreements with several states in the littoral IOR to gain military access to their bases. This effort supports the geopolitical positioning of New Delhi as it looks to counter Beijing's "string of pearls" (Thakker, 2019).

The strengthening of bilateral naval cooperation with France and the United States which grants India the access to port facilities in the U.S. base on Diego Garcia and the French base on Reunion Island are also another step taken by Indian naval in affianced with forces outside of the IOR. Australia and Japan are also involved through the informal "Quadrilateral Security Dialogue", or the "Quad," as a crucial step for the 
United States to further cooperate with India in "balancing" China presence in IOR. It also highlights India's growing geo-strategic influence in the IOR which is shown by France's participation in the creation of "Paris-New Delhi-Canberra" axis in the IndoPacific (Thakker, 2019).

The joint exercise in the region is the physical sign of India's rising military profile. India's "Malabar" naval exercise is concluded with the twenty-second iteration, which started as a bilateral exercise with the U.S. Navy and was extended to include the "Japanese Maritime Self-Defense Force" in 2015 (Thakker, 2019). The joint exercise of Malabar is considered as the most significant Indian bilateral naval effort which is mostly conducted in the Indian Ocean.

According to a defense ministry, the naval cooperation between three democratic countries namely India, the US and Japan indicates strong and resistant relationship. The Malabar series of exercise, initiated in 1992 between the Indian and US Navies, have continuously progressed in scope, complexity and contribution into a multifaceted exercise with the participation of Japanese Maritime Self Defense Force (JMSDF) (Shukla, 2017).

\begin{tabular}{|c|c|c|c|c|c|c|c|}
\hline Year & India & US & Japan & Others & Total & $\begin{array}{l}\text { Aircraft } \\
\text { carriers }\end{array}$ & Remarks \\
\hline 2005 & 4 & 4 & - & - & 8 & - & \\
\hline 2006 & 5 & 5 & - & 1 & 11 & 2 & One Canadian vessel \\
\hline $2007-1$ & 5 & 7 & 4 & - & 16 & - & \\
\hline $2007-2$ & 8 & 13 & 2 & 3 & 26 & 3 & $\begin{array}{l}\text { Two Australian and } \\
\text { one Singaporean vessel }\end{array}$ \\
\hline 2008 & 6 & 6 & - & - & 12 & 1 & \\
\hline 2009 & 3 & 4 & 2 & - & 9 & - & \\
\hline 2010 & 5 & 5 & - & - & 10 & - & \\
\hline 2011 & 5 & 7 & - & - & 12 & - & \\
\hline 2012 & 5 & 5 & - & - & 10 & - & \\
\hline 2013 & 2 & 1 & - & - & 3 & - & \\
\hline 2014 & 3 & 5 & 2 & - & 10 & - & \\
\hline 2015 & 4 & 3 & 1 & - & 8 & 1 & \\
\hline 2016 & 4 & 5 & 1 & - & 10 & $1^{*}$ & $\begin{array}{l}\text { Japan's JS Hyuga, a helicopter } \\
\text { carrier, also participated }\end{array}$ \\
\hline 2017 & 9 & 6 & 2 & - & 17 & $2^{*}$ & $\begin{array}{l}\text { Japan's JS Izum o, a helicopter } \\
\text { carrier, also participated }\end{array}$ \\
\hline
\end{tabular}

Figure 5. India Biggest Presence in Malabar (Shukla, 2017)

Throughout Prime Minister Narendra Modi's first visit to Washington in September 2014, New Delhi and Washington "agreed to upgrade their existing bilateral exercise Malabar". This was repetitive through "President Barack Obama's January 2015 visit to New Delhi". In spite of these intentions, the 2015 and 2016 Malabar exercises convoluted merely four Indian ships. This year, Indian contribution has more than doubled (Shukla, 2017). India is an active participant in the bilateral cooperation of Malabar (Figure 5). The number of forces involved in the operation has grown from the years 2009 to 2017. The effort of bilateral cooperation is more significant to support India's unilateral effort in making balance of power in the Indian Ocean in responding China's naval presence in the region. 


\section{CONCLUSION}

Indian Ocean is a crucial part of the region and became the center of the current global politics. The northern part of Indian Ocean Region (IOR) hasseveral key parts of the seas like straits, gulfs and bays. The Indian Ocean is linked to other main water bodies on the earth which creates interconnected shipping lanes connected by strategic waterways and choke points. In persisting the maritime power, good geostrategic is one of the important aspects toachieve, as seen through the spread of archipelagos and islands which becomes the striking feature of the IOR. Besides, Indian Ocean is also known by the presence of its rich natural resources. Its abundance of natural wealth has became a unique feature of the IOR and caused an increase in the number of human activities in the region. The activities are including the trade of export and import, and the oil and minerals exploration. Those actions influence the political, economy and military aspects of the states in the international system. Various states compete with each other to strengthen their presence in the IOR. This situation has caused the resources of the Indian Ocean to be very valuable in fulfilling their national security interests.

Indian Ocean Region is heavily prioritized in India's national interests. The Indian Ocean is important for India, since it is the littoral's most populated country. India is definitely trying to maintain their national security interests in Indian Ocean. The expanding activities and developments in the IOR create a new prospect and challenges for the nation states in the region and for those wishing to take advantages of these opportunities.

China is seen as an emerging threat for the welfares of India as it has rigorously build-up its naval presence in the Indian Ocean. Nowadays, China is leading a superior military existence in the area and it also proved the significant security interests of China in the Indian Ocean region. Preservation of its maritime trading lines, particularly those transporting both of oil and gas are China's main national interests which drove China to significantly elevate its military presence in the Indian Ocean.

India implements its Indian Maritime Doctrine implemented through Indian Navy application, which aims to stabilize the presence of Chinese Navy in the area since 2008. This implementation brings the sources of its naval application as an effort to correspond China's naval existence in the IOR through its doctrine. The unilateral naval effort is made to balance China in IOR. Moreover, other effort from the Indian navy is needed through bilateral cooperation that will further support her unilateral effort in countering China's naval presence in the region.

\section{References}

Agastia, I., \& Perwita, A. (Eds.). (2016). Maritime Security in the Indo-Pacific. PT. Graha IImu.

Boquérat, G. (2018). India's response to China's assertiveness over the seas. Fondation Pour La Recherche Stratégique. https://www.frstrategie.org/en/publications/notes/indias-response-chinasassertiveness-over-seas-2018 
Bueger, C. (2015). What is maritime security? Marine Policy, 53, 159-164. https://doi.org/https://doi.org/10.1016/j.marpol.2014.12.005

Central Institute of Fisheries Technology (CIFT). (2018). Central Institute of Fisheries Technology (ICAR CIFT). Indian Research of Agricultural Research (ICAR). http://cift.res.in/export-trend

Cooper, Z. (2018). Security Implications of China's Military Presence in the Indian Ocean. https://www.csis.org/analysis/security-implications-chinas-militarypresence-indian-ocean

Dravid, A. (2018). China's Rise and Indian Ocean Ambitions. Center for International Maritime Security (CIMSEC). http://cimsec.org/chinas-rise-indian-oceanambitions/36668

Dutta, S. (2018). "Alphabet soup" of Navy missions dots Indian Ocean. The Indian Express.

https://www.newindianexpress.com/thesundaystandard/2018/apr/01/alphabetsoup-of-navy-missions-dots-indian-ocean-1795343.html

Fatima, Q., \& Jamshed, A. (2015). The Political and Economic Significance of Indian Ocean: An Analysis. In South Asian Studies A Research Journal of South Asian Studies (Vol. 30, Issue http://www.rsis.edu.sg/research/PDF/emerge_maritime_security.pdf

Food and Agriculture Organization. (2016). The State of World Fisheries and Aquaculture 2016. Contributing to food security and nutrition for all.

Ghosh, P. K. (2014). Maritime Security Trilateralism: India, Sri Lanka and Maldives. Strategic Analysis, 283-288. https://doi.org/10.12724/ajss.39.1

Gupta, S. (2018). Union Budget 2018: Defence allocation unlikely to go up. Hindustan Times. https://www.hindustantimes.com/india-news/defence-budget-unlikely-togo-up/story-5z0wi3gn1QdzqBoC0iYtGI.html

India Foundation. (2016). Global Power Transition and the Indian Ocean. http://indiafoundation.in/global-power-transition-and-the-indian-ocean/

Jaishankar, D. (2016). Indian Ocean region: A pivot for India's growth. Brookings. https://www.brookings.edu/opinions/indian-ocean-region-a-pivot-for-indias-growth/

Matheswaran, M. (2018). Military modernisation: where is the money? Deccan Herald. https://www.deccanherald.com/opinion/panorama/military-modernisation-where676864.html

Ministry of Defense (Navy). (2009). Indian Maritime Doctrine. https://www.indiannavy.nic.in/sites/default/files/Indian-Maritime-Doctrine-2009Updated-12Feb16.pdf

Mukherjee, T. (2018). China's Maritime Quest in the Indian Ocean: New Delhi's Options. The Diplomat. https://thediplomat.com/2018/04/chinas-maritime-quest-inthe-indian-ocean-new-delhis-options/ 
$\mathrm{Ng}, \mathrm{T} .$, \& Jiangtao, S. (2017). Chinese navy's live-fire drill may be warning shot to India amid ongoing Doklam stand-off. South China Morning Post. https://www.scmp.com/news/china/diplomacy-defence/article/2108410/chinesenavys-live-fire-drill-may-be-warning-shot-india

Page, J., \& Lubold, G. (2015). Chinese Navy Ships Came Within 12 Nautical Miles of U.S. Coast. The Wall Street Journal. https://www.wsj.com/articles/chinese-navyships-off-alaska-passed-through-u-s-territorial-waters-1441350488

Pasricha, A. (2018). India Moves to Counter Growing Chinese Presence in Indian Ocean Region. VOA News. https://www.voanews.com/a/india-moves-countergrowing-chinese-presence-indian-ocean-region/4236174.html

Pisupati, B. (2015). Redefining SAGAR in Indian Ocean. The Hindu. https://www.thehindu.com/sci-tech/energy-and-environment/redefining-sagar-inindian-ocean/article7248385.ece

PMINDIA. (2015). Text of the PM's remarks on the Commissioning of Coast Ship Barracuda. http://www.pmindia.gov.in/en/news_updates/text-of-the-pms-remarkson-the-commissioning-of-coast-ship-barracuda/

PTI. (2018a). India to protect its interest in Indian Ocean Rim, says MoS for Defence Rao Inderjit Singh. The Economic Times. https://economictimes.indiatimes.com/news/defence/india-to-protect-its-interest-inindian-ocean-rim-says-mos-for-defence-rao-inderjitsingh/articleshow/47109764.cms

PTI. (2018b). Navy to implement new plan for warships in Indian Ocean region. The Economic Times. https://economictimes.indiatimes.com/news/defence/to-counterchina-navy-to-implement-new-plan-for-warships-in-indian-oceanregion/articleshow/61231821.cms?from $=\mathrm{mdr}$

Samaranayake, N. (2017). Traditional and Non-traditional Issues in Indian Ocean. In Policy Recommendations by the Quadripartite Commissionon the Indian Ocean Regional Security (p. 179).

Sethi, A. S. (2017). New Chinese Naval Deployments In Indian Ocean, Indian Navy Outgunned One To Four. Bloomberg Quint. https://www.bloombergquint.com/politics/new-chinese-naval-deployments-inindian-ocean-indian-navy-outgunned-one-to-four\#gs.tO1fDOUI

Shukla, A. (2017). Amid Sino-India tension, biggest navy participation in Malabar exercise. Business Standard. https://www.business-standard.com/article/currentaffairs/amid-sino-india-tension-biggest-navy-participation-in-malabar-exercise117071100075_1.html

Suri, G. (2017). China's Maritime Military Activity in the IOR. In China's Expanding Military Maritime Footprints in the Indian Ocean Region (IOR) (pp. 87-100). Pentagon Press.

Thakker, A. (2019). A Rising India in the Indian Ocean Needs a Strong Navy. Center for Strategic and International Studies. https://www.csis.org/npfp/rising-indiaindian-ocean-needs-strong-navy 
The Shipping Corporation of India Limited. (2016). 66th Annual Report 2015 - 2016.

The Times of India (Mumbai Edition). (2017). Navy sat spots surge in Chinese naval ships. PressReader.Com. https://www.pressreader.com/india/the-times-of-indiamumbai-edition/20170704/282140701401242

whatarethe7continents. Indian Ocean. (2018). Author. https://www.whatarethe7continents.com/indian-ocean/

Xinhua. (2017). Chinese naval fleet stages live-fire drill in Indian Ocean. http://www.xinhuanet.com/english/2017-08/25/c_136555350.htm

Yang, T. (2018). China Unlikely to Match India Strength in Indian Ocean in Near Future - Analysts. Sputnik News. https://sputniknews.com/analysis/201803051062243930-china-india-indian-ocean/

Yarger, H. R. (2006). Strategic Theory for the 21st Century: The Little Book on Big Strategy. Carlisle: Strategic Studies Institute. 